\title{
Self-Assessment Of Households'
}

\section{Economic Welfare}

\section{As A Manifestation Of Adjustment To Transition}

\section{And European Integration Processes In The Case Of Estonia}

Tiiu Paas, (Email: tpaas@ut.ee), University of Tartu, Estonia Andres Võrk, (Email: andres.vork@ut.ee), University of Tartu, Estonia Nancy J. Scannell, (Email: scannell.nancy@uis.edu) University of Illinois - Springfield

\begin{abstract}
This paper analyzes Estonian households' perception of welfare, including the determinants and dynamics of said perception under transition. Data from the Estonian Household Income and Expenditures Survey 2000 and 2001 are used to construct samples. Ordered probit and linear regression models are employed to investigate the determinants of the self-assessed economic situations and income levels as determined to be necessary by households for conducting normal life. The income level perceived by households as necessary to conduct normal life is found to vary substantially depending on a given household's actual income and other extant household characteristics. This indicates that factors other than income per capita alone are relevant for understanding households' welfare and their perception of normal life, and, hence, should be among the targets of social policy and factored into the development strategies of Estonia's social protection system.
\end{abstract}

\section{Introduction}

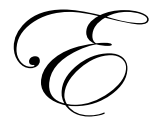

stonia has endured in excess of a decade of economic reforms and structural adjustments, which culminated in severe, present-day social maladies and the imposition of substantial costs that are likely to impede the processes of Estonian reintegration into Europe and its transition as a new entrant into the European Union (EU). The often surprisingly intensive pace of, in effect, the transformation processes has levied hefty pressures on the Estonian populace whose absorptive powers are naturally limited. Manifestations of the negative ramifications include poverty, social exclusion, widening inequalities and the emergence of structural unemployment in Estonia.

Under its former central planning regime, Estonia, like other post-socialist countries, was characterized by a more egalitarian income distribution than that typically ascribed to western market economies. This situation in Estonia, however, has been dramatically altered since the onset of transition in the early 1990s which fostered an expeditious escalation of income inequality far beyond that experienced in any of the established market economies during the same period. By 1993 alone, income inequality in Estonia caught up with the average level observed in EU and OECD countries. Prior studies have shown that people from post-socialist countries are less tolerant of existing income inequalities, even after the actual degree of income inequality and other determinants of attitudes are taken into account (see Suhrcke 2001). 
Poverty is primarily identified with individuals and households, whereas social exclusion contemplates the relationship that an individual economic unit maintains with society as a whole. Social exclusion in Estonia can be characterized as inadequate social participation and integration due to abrupt and rapid changes in households' economic lives and a severance of social bonds between the individual and society. Social exclusion can also be regarded as a like property of societies (see also Gore and Figueiredo, 1997). Poverty is arguably a cause as well as a consequence of social exclusion when taking into account distributional issues and deficiencies in material and social resources.

\section{Study Objective and Approach}

Numerous poverty studies of Estonia exist that essentially apply an indirect analytical approach, emphasizing absolute versus relative poverty levels (Kutsar and Trumm (eds.), 1999; Kuddo, et al, 2002; Wilder and Viies, 2001; Household Living Niveau..., 2002). The purpose of the present study is to analyze Estonian households' perceptions of welfare, including the determinants and dynamics of said perceptions, throughout the country's protracted transitional phase, relying on reported self-assessments of households' economic situations (or conditions).

In order to fulfill the objective of the study, considerations regarding the concepts of poverty and social exclusion are entertained, which facilitate the portrayal of the Estonian population's adjustment phase as it undergoes market transition and adherence to EU integration imperatives. The data and research methodology are then introduced. The primary data source used in the paper is the Estonian Household Income and Expenditures Survey carried out by the Statistical Office of Estonia. Based on the data involving self-assessment of Estonian households' economic situations, the aforementioned adjustment phase is evaluated. The latter portion of the paper presents empirical results from an analysis of the Estonian households' self-assessed economic situation and, subsequently, renders a determination of the degree of successfulness of Estonian society's adjustment to transition and integration processes.

\section{Poverty Thresholds}

The concept of poverty is broadly defined as a person's inability to afford an adequate standard of consumption. Already nebulous, the definition suffers further from the ambiguousness of the qualifier, adequate. Further contributing to the elusiveness of the term, 'poverty' receives variable treatment contingent on its contextualization with respect to geography, time, and other factors. Ultimately, the concept of poverty is necessarily contended with in both objective and subjective terms.

Furthermore, economists ordinarily regard poverty in both absolute and relative terms. According to the absolute approach, determination of the poverty line is accomplished by considering the essential resources (food, clothing, housing, transport, communication, etc,) that an average human adult consumes in one year and then summing their costs. The weightiest of these resources is typically the rent required to live in an apartment, so historically economists have paid particular attention to the real estate market and housing prices as strong poverty line determinants (Word I-Q.com, 2004). Poverty in absolute terms is, thusly, defined as a consumption level short of a given fixed threshold of minimum consumption requirements.

The relative approach interprets poverty in relation to the prevailing living standards of the society at large, recognizing the interdependence between the poverty line and the entire population income distribution. Two approaches are utilized in defining the relative poverty line (Anand, 1997; pp. 242-279: 1). First, the poverty line is defined as the income level, $p$ as a percent of a given population income, below which a population faction is deemed in poverty. The choice of $p$ is arbitrary in the sense that having an income marginally above $p$ is not substantially different from having an income marginally below $p$. Second, relative poverty is denoted vis-à-vis contemporary living standards. A relative income line can be related to some fraction of typical incomes (Word IQ.com, 2004). Poverty in relative terms will, by construct, never disappear. John Black in the Oxford Economic Dictionary (Black, 1997, p. 360) notes that if an absolute standard of poverty is accepted, it is at least conceivable 
that technical progress will eventually lift everybody above the poverty line (closing the poverty gap), but if poverty is relative, the poor, will always exist.

Various entities have made determinations with regard to demarcations of a poverty line. As noted in Table 1, per the World Bank, the poverty line is situated at 2.15 or 4.30 USD (PPP) per capita per day, depending on the level of development of a country, its geographical location, and other characteristics. The EU poverty line is set at $60 \%$ of the national median income, and UNICEF establishes its poverty line at $35-40 \%$ of average salary (EC, 1998, Social Protection Committee, 2001; World Bank, 2000; Kuddo, et al, 2002).

Table 1. Poverty Line Thresholds by International Organization

\begin{tabular}{|l|l|}
\hline International organization & Poverty line indicators \\
\hline World Bank & $\begin{array}{l}2.15 \text { or 4.30 USD (PPP) per capita per day (depending on the level of } \\
\text { development of a country, it's geographical location, etc) }\end{array}$ \\
\hline $\begin{array}{l}\text { European Union (Social Protection } \\
\text { Committee, 2001) }\end{array}$ & $60 \%$ of the national median income \\
\hline $\begin{array}{l}\text { UNICEF (United Nations } \\
\text { Children's Fund) }\end{array}$ & $35-40 \%$ of average salary \\
\hline
\end{tabular}

Sources: EC, 1998, Social Protection Committee, 2001; World Bank, 2000; Kuddo, et al, 2002.

In addition to (aforementioned) level of development and geography, methods for calculating and implementing cut-off points vary significantly among countries and regions depending on culture, habits, norms of consumption, and other characteristics.

When comparing the corresponding indicators with the EU it should be born in mind that the data of EU countries were collected with surveys which in some manner employ a different methodology (the equivalence scales $1: 0.5: 0.3$ were used in the EU, 1: $0.8: 0.8$ in Estonia). The poverty line is the same $-60 \%$ of national median income. This income does not include irregular income and income from the sale of assets.

\section{Social Exclusion}

Poverty is generally contextualized within a multidimensional framework. The term, poverty, conjures up a situation where an individual or a group of persons finds her/himself or themselves with abjectly scarce material and social resources. Such persons face extreme difficulties in obtaining the necessary means to provide for nutritious food, shelter, clothing, medical care, and education. They cannot afford to meet cultural and intellectual needs. They feel insecure about the future and foresee no prospect for improvement in life. A serious consequence of poverty is exclusion of those afflicted from participating in the socio-economic sectors of society. Exclusion of this variety is thought to exacerbate the poverty picture, and, in turn, further the degeneration of human capital and deterioration of a country's competitiveness.

A contemporary debate lingers over the question as to whether the phrase, "poverty is multidimensional", connotes that 1) poverty itself relates to income, but the causes of poverty are multidimensional or 2) the concept of poverty is multidimensional and relates to more than just income (Poverty Reduction..., p.38). Sometimes the terms 'poverty' and 'social exclusion' have been used synonymously with reference to the multidimensional concept of poverty.

The concept 'social exclusion' was addressed in 1985 by Jacques Delors, the former president of the European Commission. In the same year, the European Poverty Program was expanded to include the issue of social exclusion. It was recognized that the concept 'social exclusion' more appropriately allows for a broader analysis of a multitude of current societal problems like unemployment, instability of families, shortage of welfare benefits and international migration in a common framework (Rodgers, et al, 1995). Social exclusion is now commonly used as a 
more comprehensive notion than poverty. The impact of social exclusion on people is manifest in poor living conditions and observable at the level of households and individuals.

The causes of social exclusion are attributable to the failure of, for one, institutions to integrate individuals into society. The analyses of various research studies and approaches (Gaudier, 1993; Silver, 1994; Berghman, 1998) afford credibility to the suggestion asserted by Regina Berger-Schmitt and Heinz-Herbert Noll (2000, p. 18), that social exclusion should more broadly be conceptualized as a like failure of one or more of the following four systems: The democratic and legal system promoting civil integration; the labor market promoting economic integration; the welfare state system promoting social integration; and the family and community systems promoting interpersonal integration.

In the case of Estonia, as with other transitional countries, the causes of social exclusion are interrelated. It is plausible that self-assessment of Estonian households' economic welfare is strongly influenced by the dynamics of the adjustment of the Estonian population to the transition processes and by the successfulness of economic and social integration of the Estonian society. Information garnered with respect to the Estonian households' selfperception of their welfare will likely have important implications for the scale of political support for reform policy exercised and for underscoring the necessity to soberly deal with social consequences of the transition and European integration processes in Estonia.

Social exclusion can be explicated, in part, by the failure of institutions, most particularly failures germane to labor market institutions. The Estonian labor market is very flexible, especially in comparison with the EU member states' average (see also Paas, et al, 2003). Estonian trade unions are small and weak. Labor market policy is insufficiently funded, and the share of active measures is relatively low, to wit, $28 \%$ of the overall employment policy budget. Expenditures on active labor market measures account for only $0.06 \%$ of GDP in Estonia, a diminutive fraction compared to the corresponding average rate of $1.12 \%$ in the EU. The low level of expenditure on active labor market measures promotes the exclusion of some segment of the unemployed population from the labor force.

\section{Data and Methodology}

In this study, micro-level data from years 2000 and 2001 were taken from Estonian Household Income and Expenditures Survey carried out by the Statistical Office of Estonia. The Survey is carried out on a continuous basis; each month more than six hundred households are interviewed and monitored, totaling roughly eight thousand households in each of both years. The Survey provides information on households' income and expenditure, structure and main social and demographic characteristics, living conditions and self-assessment of their economic situation. All households who live legally and permanently in Estonia are considered within the population to be studied. Persons who live in institutional households are excluded. The frame of the study is the population register, from which a stratified sample of persons is drawn. In the empirical statistical and econometric analyses appropriate survey weights are assigned.

In calculating Estonia's absolute poverty line, the levels of minimal expenditures by household members were taken as a starting point. The minimal expenditure consists of 1) costs of a minimal food basket, 2) housing costs, and 3) basic clothing, education and transport expenditures. The absolute poverty line is a dynamic indicator, which is adjusted annually in line with changes in the cost of living. In Estonia the settled level of minimum expenditure was 78.6 euros (1226 Estonian Kroon or EEK) per household member (per month) in 2000. At the same time, the cost of a minimal food basket was 38 euros (593 EEK). This poverty line comprised $70.3 \%$ of national median per capita income, high in comparison with that set by European Union standards (see Table 1). In 2001 the share of Estonian population living below the poverty line in accordance with EU rules (76.7 euros or 1196 EEK) was 17\% (Household Living Niveau, 2002, pp. 34-37 and p. 60). The average share of population living below the poverty line was roughly $17 \%$ for the 15 member states of the EU in 1996 as well. 


\section{Poverty: Direct and Indirect}

In addition to categorizing poverty in absolute versus relative terms, poverty assessment can be explored via direct versus indirect approaches. The indirect approach estimates the resources that a person possesses and assumes that this quantum reveals her/his living standard. The baseline indicators for indirect assessment of poverty are the absolute and relative poverty lines.

The direct approach to poverty assessment attempts to measure poverty based on a person's evaluation of her/his own welfare, which is contingent upon individual behavior and preferences. Thus, the fact that resources may be equal in monetary terms for two entities does not infer that the derived welfare is evaluated uniformly by both entities. Thus, the results of direct assessment of poverty more intimately capture an expression of the Estonian population's adjustment to the transition and integration processes better than the results of indirect assessments of poverty. The households' self-assessment results also characterize the level of social exclusion as a property of society.

As indicated in Table 3, comparisons of indirect and direct measures of poverty were weighed using households' income per capita, self-evaluation of the households' economic situation and the income per capita considered necessary to conduct a normal life. Each household faced a choice of five suggested portrayals of selfassessment of their individual economic situations as follows: 1) can consume without any restrictions; 2) can afford everything needed for a normal life; 3) can manage generally; 4) can make both ends meet; and 5) living in very poor conditions. These five choices are listed in Table 2 along with data totals.

Table 2. Self-Assessment of Estonian Households' Economic Situations in 2001; Direct Approach (\% of Responded Households)

\begin{tabular}{|l|c|c|c|}
\hline Options for Assessment & $\begin{array}{c}\text { Share of Households } \\
(\%)\end{array}$ & \multicolumn{2}{|c|}{$\begin{array}{c}\text { Households } \\
\text { Divided By Relative Poverty Line (\%) }\end{array}$} \\
\cline { 3 - 4 } & & 0.6 & Below \\
\hline $\begin{array}{l}\text { 1) Can consume without any } \\
\text { restrictions }\end{array}$ & 0.4 & 7.8 & 0.1 \\
\hline $\begin{array}{l}\text { 2) Can afford everything needed } \\
\text { for a normal life }\end{array}$ & 7.0 & 40.4 & 2.2 \\
\hline 3) Can manage generally & 35.7 & 48.2 & 17.3 \\
\hline 4) Can make both ends meet & 50.1 & 3.0 & 22.2 \\
\hline $\begin{array}{l}\text { 5) Living in very poor } \\
\text { conditions. }\end{array}$ & 6.8 & 100 & 100 \\
\hline Totals & 100 & & \\
\hline
\end{tabular}

Source: Estonian Household Income and Expenditure Survey, Statistical Office of Estonia; authors' calculations.

According to results based on the indirect approach to poverty level evaluation in Estonia, the share of Estonian population living below the poverty line is nearly the same as the EU average. In contrast, the results of the direct approach as presented in Table 2 show, according to the households' self-evaluations, more than one half of households 'living in very poor conditions' or 'can make both ends meet' $(6.8 \%+50.1 \%) ; 35.7 \%$ of households 'can manage generally'; and only $7.4 \%$ of households 'can afford everything needed for a normal life' or 'can consume without any restrictions' $(7 \%+0.4 \%)$.

Table 2 also presents the self-assessment results of households depending on whether their incomes fall above or below the relative poverty line. (The poverty line is defined as $60 \%$ of Estonia's national median income in line with EU standards, as mentioned earlier.) Here, the results of the direct approach indicate a general consensus with indirect poverty measure approaches. Compared with households above the poverty line, households below the poverty line responded with larger and smaller shares, respectively, in the categories of 'living in very poor 
conditions' and 'can afford everything needed for a normal life'. Notwithstanding, even among households below the poverty line, there is a positive, albeit small $(0.1 \%)$, share of the population who reported 'can consume without any restrictions'. Conversely, among households above the poverty line, a similarly small (3\%) share of households reported 'living in very poor conditions'. A realization, drawing from Table 2 data, is that to consider either the direct approach or indirect approach in isolation would be short-sighted. The disparate measures may lead to different and perhaps even conflicting conclusions when attempting to identify poor households. Potential negative repercussions include an unwitting misdirection of economic policy instruments and, accordingly, a misappropriation of resources towards an erroneously-profiled poor constituency.

The self-assessment results of the Estonian households' economic situations readily support the aforementioned assertion that not all people have uniformly shared in the country's recognized economic successes. Perhaps more remarkable is the substantial combined share $(50.1 \%+6.8 \%)$ of households that report situations substandard to the category, 'can manage generally'. This combined share, $56.9 \%$, is three times in excess of the share of population living below the poverty line per established EU guidelines.

\section{Five-Year Comparisons of Welfare}

To elicit Estonian households' perspectives of changes in their welfare status over five of the country's transition years, 2001 versus 1996, and 2000 versus 1995, households were asked to select one from among five phrases which most accurately describes their comparative status. Figure 1 presents the results of the survey.

Figure 1. Distribution of Households by Self-Evaluation of Changes in their Economic Situations Between Year Pairs, 1996 - 2001 and 1995 - 2000

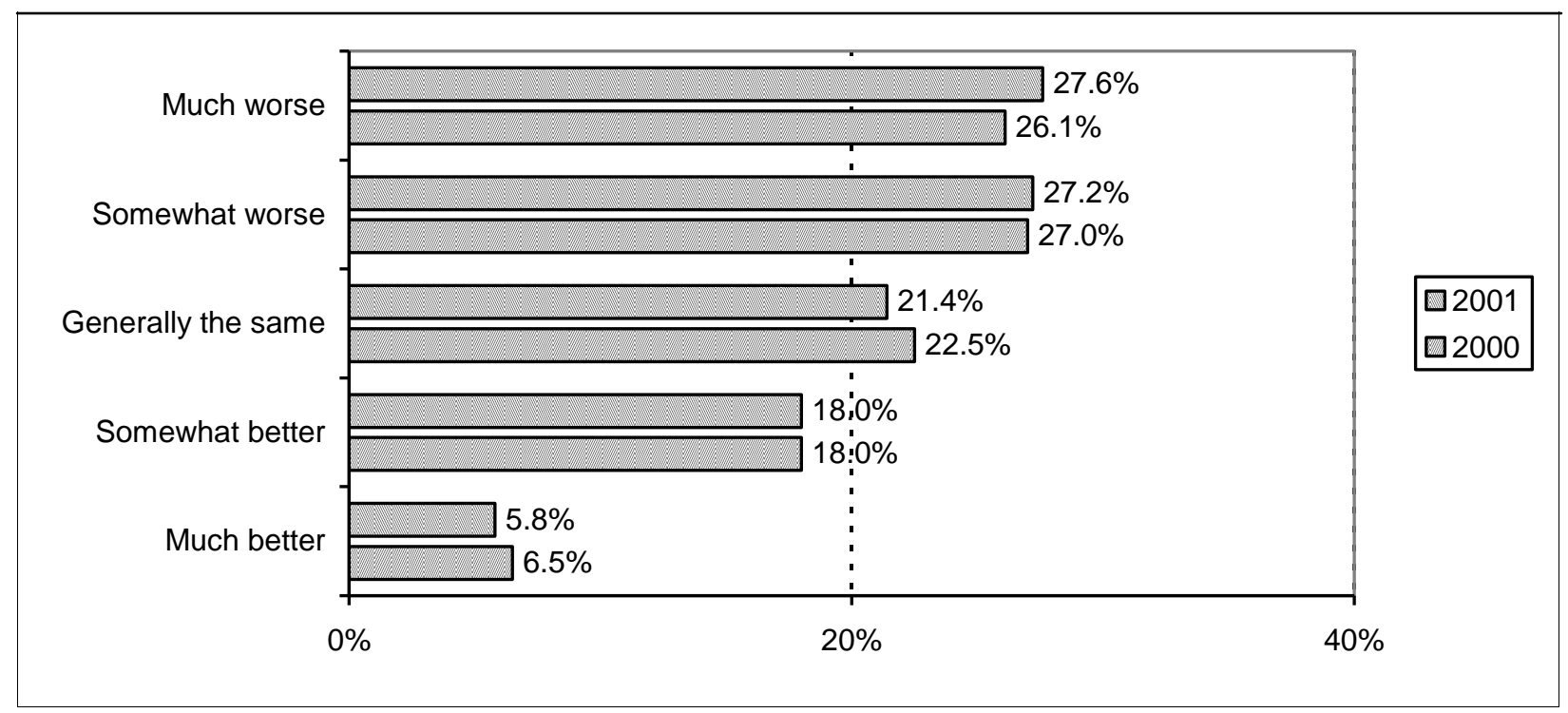

Source: Statistical Office of Estonia, authors' calculations.

As seen in Figure 1, more than a half of households evaluate their economic situation in 2001 as much worse or somewhat worse than in 1996. Similar results characterize the contrast between years 2000 and 1995. Taken together, these results are intriguing. In 1996, for example, the Estonian economy could be likened to that observed in years 1993-1994. However, between 1996 and 2001 Estonia's GDP per capita nearly doubled, and average salaries rose approximately 1.8 times. In spite of this otherwise impressive economic growth, Estonian households are reportedly inordinately critical about their own welfare. It might be fair to say that household expectations regarding economic welfare improvements surpass the otherwise striking realized state of affairs. The 
seeming incongruity warrants speculation as to the occurrence of some rupture of relationship between individual and society.

\section{Capturing Households' Gauges of 'Normal' and 'Necessary'}

Inevitably, a question emerges as to what Estonian households mean by an 'income necessary to conduct normal life.' Table 3 helps to shed some light on this issue.

Table 3. The Households' Actual Monthly Income and the Income Necessary to Conduct Normal Life in 2001 (Euros per Households' Member)

\begin{tabular}{|l|c|c|c|}
\hline Options for Assessment & Necessary Income & Actual Income & $\begin{array}{c}\text { Ratio of Necessary to } \\
\text { Actual Incomes }\end{array}$ \\
\hline $\begin{array}{l}\text { 1) Can consume without } \\
\text { any restrictions }\end{array}$ & 428 & 422 & 1.01 \\
\hline $\begin{array}{l}\text { 2) Can afford everything } \\
\text { needed for a normal life }\end{array}$ & 340 & 301 & 1.13 \\
\hline 3) Can manage generally & 278 & 194 & 1.43 \\
\hline $\begin{array}{l}\text { 4) Can make both ends } \\
\text { meet }\end{array}$ & 228 & 115 & 1.98 \\
\hline $\begin{array}{l}\text { 5) Living in very poor } \\
\text { conditions. }\end{array}$ & 206 & 72 & 2.87 \\
\hline Averaged Values & 253 & 155 & 1.63 \\
\hline
\end{tabular}

Source: Estonian Household Income and Expenditure Survey, Statistical Office of Estonia; authors' calculations.

Table 3 disaggregates Estonian households based upon their self-assessed claims to one of five options reflecting degrees of economic living conditions. Households in very poor conditions (option 5) consider necessary income needed for normal life less than half (206) that acknowledged by households who can consume without any restrictions (option 1). Comparing the actual average income with average income considered necessary for a normal life (bottom row of Table 2), we can crudely estimate the amount of money required to fill the income gap and, thus, elevate all households to the level of 'can afford everything needed for a normal life' at between 9.4 and 10.3 billion Estonian Kroon (EEK) per year, which measures approximately 10\% of GDP. Table 4 divulges the relevant calculations. (As a point of reference, in the year 2001, social assistance benefits comprised only 350 million EEK or 22.4 million euros, where one euro equals 15.625 EEK.)

Table 4. Filling the Income Gap

\begin{tabular}{|l|l|l|l|l|l|l|l|}
\hline $\begin{array}{l}\text { Actual average monthly } \\
\text { after-tax income per hh } \\
\text { member }\end{array}$ & $\begin{array}{l}\text { Income considered } \\
\text { necessary for normal life } \\
\text { per hh member }\end{array}$ & $\begin{array}{l}\text { Estimated number of } \\
\text { housholds in the } \\
\text { population, according to } \\
\text { the survey }\end{array}$ & \multicolumn{2}{l|}{$\begin{array}{l}\text { Difference of estimated } \\
\text { sum, per year in million } \\
\text { of EEK for all housholds }\end{array}$} \\
\hline $\mathbf{2 0 0 0}$ & $\mathbf{2 0 0 1}$ & $\mathbf{2 0 0 0}$ & $\mathbf{2 0 0 1}$ & $\mathbf{2 0 0 0}$ & $\mathbf{2 0 0 1}$ & $\mathbf{2 0 0 0}$ & $\mathbf{2 0 0 1}$ \\
\hline 2319 & 2420 & 3716 & 3948 & 560847 & 562572 & $\mathbf{9 4 0 4}$ & $\mathbf{1 0 3 1 5}$ \\
\hline 1013 & 1117 & 2924 & 3222 & 30123 & 35892 & 691 & 907 \\
\hline 1694 & 1800 & 3283 & 3560 & 277124 & 280585 & 5286 & 5924 \\
\hline 2893 & 3027 & 4155 & 4337 & 210444 & 205369 & 3187 & 3229 \\
\hline 4305 & 4697 & 4745 & 5298 & 39321 & 38886 & 208 & 280 \\
\hline 5859 & 6583 & 7580 & 6677 & 3835 & 1738 & 79 & 2 \\
\hline & & & & & & $\mathbf{9 4 5 1}$ & $\mathbf{1 0 3 4 2}$ \\
\hline
\end{tabular}




\section{Probit Modeling}

In order to study the self-assessed current (referring to the more recent years of study, 2000 and 2001) economic situation of Estonian households with respect to the households' socio-demographic characteristics, we estimate ordered probit and linear regression models. As presented in Table 4, we consider two dependent variables: a) self-assessed poverty (in the ordered probit model), and b) the necessary monthly income per household member for normal life (in the linear regression model). Explanatory variables are the socio-demographic characteristics of the household and household's head, and actual income per household member. The regression modeling results presented in Table 5 indicate that even after controlling for actual income per capita, considerable differences remain in households' direct assessment of economic situations.

Table 5. Empirical Results of the Regression Models ${ }^{+}$

\begin{tabular}{|c|c|c|}
\hline \multirow{2}{*}{ Explanatory Variables } & \multicolumn{2}{|c|}{$\begin{array}{c}\text { Dependent Variables And Method } \\
\end{array}$} \\
\hline & $\begin{array}{l}\text { Self-assessed economic situation } \\
\text { (ordered probit model) }\end{array}$ & $\begin{array}{c}\text { Required income per capita } \\
\text { (1000s) (OLS with robust } \\
\text { standard errors) }\end{array}$ \\
\hline Head is Estonian & $\begin{array}{c}0.172 \\
(6.32)^{* * *}\end{array}$ & $\begin{array}{c}0.116 \\
(1.79)^{*}\end{array}$ \\
\hline Head is male & $\begin{array}{c}0.231 \\
(10.55)^{* * *}\end{array}$ & $\begin{array}{c}0.295 \\
(5.42)^{* * *}\end{array}$ \\
\hline Age & $\begin{array}{c}-0.016 \\
(3.87)^{* * *}\end{array}$ & $\begin{array}{c}0.030 \\
(3.18)^{* * *}\end{array}$ \\
\hline Age squared & $\begin{array}{c}0.011 \\
(2.85)^{* * *}\end{array}$ & $\begin{array}{c}-0.051 \\
(5.99) * * *\end{array}$ \\
\hline Kids aged 3 years & $\begin{array}{r}0.007 \\
(0.17)\end{array}$ & $\begin{array}{c}-0.681 \\
(4.74)^{* * *}\end{array}$ \\
\hline Kids aged $4-8$ years & $\begin{array}{c}0.109 \\
(3.53)^{* * *}\end{array}$ & $\begin{array}{c}-0.612 \\
(11.15)^{* * *}\end{array}$ \\
\hline Kids aged $9-16$ years & $\begin{array}{c}0.058 \\
(3.20)^{* * *}\end{array}$ & $\begin{array}{c}-0.589 \\
(17.95)^{* * *}\end{array}$ \\
\hline Adults & $\begin{array}{c}0.187 \\
(14.35)^{* * *}\end{array}$ & $\begin{array}{c}-0.439 \\
(13.50)^{* * *}\end{array}$ \\
\hline Secondary education level & $\begin{array}{c}0.256 \\
(9.28)^{* * *}\end{array}$ & $\begin{array}{c}0.230 \\
(4.71)^{* * *}\end{array}$ \\
\hline Higher education level & $\begin{array}{c}0.721 \\
(19.65)^{* * * *}\end{array}$ & $\begin{array}{c}0.687 \\
(7.14)^{* * *}\end{array}$ \\
\hline Income per capita (1000s) & $\begin{array}{c}0.245 \\
(40.25)^{* * *}\end{array}$ & $\begin{array}{c}0.463 \\
(13.12)^{* * *}\end{array}$ \\
\hline Constant & & $\begin{array}{c}3.577 \\
(8.88)^{* * *}\end{array}$ \\
\hline Observations (n) & 11806 & 11777 \\
\hline (Pseudo) R-squared & 0.15 & 0.38 \\
\hline
\end{tabular}

${ }^{+}$Dummies for time periods and for counties were also included. Absolute values of $\mathrm{t}$ statistics are in parentheses; * significant at $10 \%$; ** significant at 5\%; *** significant at $1 \%$. Positive coefficients in the ordered probit model can be interpreted such that the corresponding variable improves households' satisfaction with the given economic situation. 
Significance of household decomposition variables (i.e., the number of adults and children of different ages) accounts for additional costs and economies of scale for the family. Important to note here is that even after controlling for actual income and family structure, households' other characteristics influence how households perceive their economic situation. Households who have a male Estonian head with a higher education level consider their household situation relatively better, and their required income per capita necessary for normal life is reportedly higher. This reinforces the notion that factors other than income per capita alone are germane to household welfare and households' perceptions of normal life.

\section{Objective and Subjective Measures}

It is useful to contemplate how one can evaluate the current situation in Estonia in terms of successfulness of people's adjustment to transition and European integration processes. According to Wolfgang Zapf (1984) who articulates the German notion of quality of life, there are objective living conditions and subjective well-being evaluations which together create a typology of welfare positions (see also Berger-Schmitt 2000, p.11). The objective living conditions are ordinarily the ascertainable living circumstances, such as material aspects, working conditions, state of health and social relations. Subjective well-being is expressed in terms of evaluations of living conditions including cognitive and affective components influenced by the peoples' positions within society. Figure 2 depicts combinations of discrete measures (good and bad) of living conditions (measured vertically) and wellbeing (measured horizontally). The hybrid of good living conditions and bad subjective well-being signifies a dissonance as recorded in the north-west quadrant of Figure 2. Bad objective living conditions combined with bad subjective well-being depicts a situation of deprivation as recorded in the south-west quadrant of Figure 2. Bad living conditions paired with good well-being is described as adaptation (south-west quadrant).

Figure 2. Assessment of Living Conditions Using Objective and Subjective Combinations

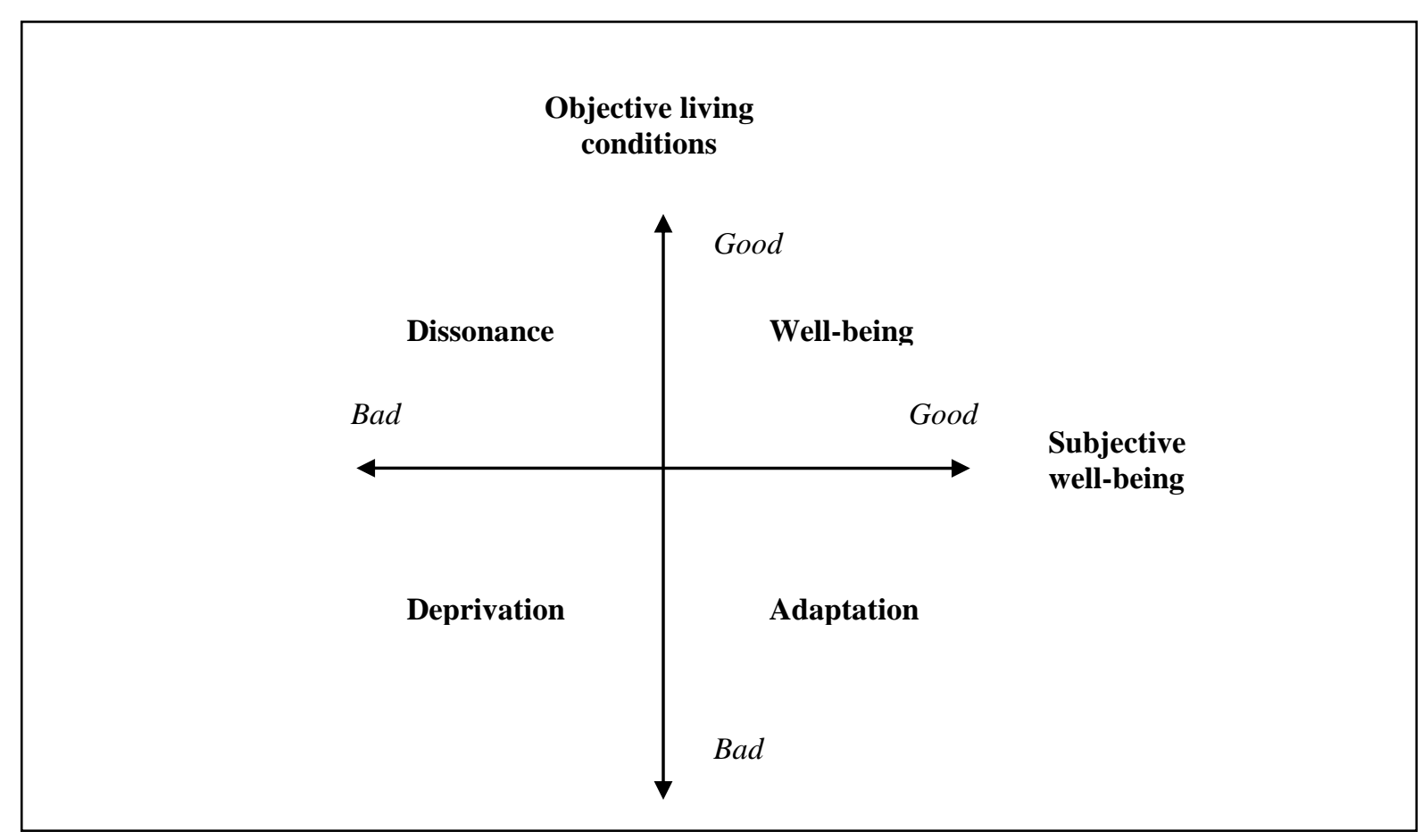

Note: Based on welfare typology of Wolfgang Zapf, 1984) 
Despite the rapid economic growth and significant increase of salaries over recent years in Estonia, objective living conditions in the country cannot be described as good, particularly when viewed within a European context. Also, the level of Estonian per capita GDP (PPP adjusted) is only about $40 \%$ of the EU countries' parallel indicator. Additionally, Estonian institutions remain rather weak in their effort to support people throughout their adjustment processes. Thus, self-assessment of households' economic situation indicates that both objective living conditions and subjective well-being of the majority of the Estonian households are bad and, accordingly, deprivation (south-west quadrant of Figure 2) epitomizes the condition of Estonian households.

The self-assessment results also draw attention to the process of adjustment of Estonian people to the changes in the labor market and to the newly instituted social protection system. An important task of Estonia's social protection system is to thwart serious social exclusion and to create and foster conditions for sustainable social development. It can be surmised that at the present time Estonian society is still predominately one of deprivation (bad objective living conditions combined with bad subjective well-being as depicted in Figure 2), and the people's adjustment to abrupt and rapid changes caused by the transition and integration processes has yet to run its course.

\section{Conclusions}

The results of the study indicate that poverty and social exclusion are serious social consequences of rapid transition and integration processes in Estonia. More than half of surveyed Estonian households' economic situations were reported as ranging from 'somewhat worse' to 'much worse' when juxtaposed to a point in time five years earlier. Similarly, more than half of households reported incomes that, by their own admissions, were below a threshold necessary to manage overall household economic activity.

Despite the swift development of the Estonian economy in recent years, only $24 \%$ of households indicate that their economic situation has improved in 2001 when compared to 1996. In spite of an otherwise impressive economic growth, Estonian households are reportedly inordinately critical about their own welfare. It might be fair to say that household expectations regarding economic welfare improvements surpass the otherwise striking realized state of affairs. The seeming incongruity warrants speculation as to the occurrence of some rupture of relationship between individual and society. It is plausible to propose that the high level of income inequality (the Gini coefficient was 0.36 in 2000) in Estonia is a causative factor in explaining the strong self-criticism of households' economic situations. Contributing further is the fact that the Estonians, like people from other post-socialist countries, are less willing to tolerate income inequalities than people from western market economies. The reason for this low tolerance is also social exclusion as a relational issue which is caused by the weak social bonds between individual and society.

The results of the study show that the income necessary for a normal life varies considerably, depending on a household's actual material living conditions. Comparing the actual average income and the income considered necessary for a normal life, we estimate that the amount of money required to elevate all Estonian households to the level of 'normal life' would be roughly $10 \%$ of GDP. We also found that even after controlling for actual income and household structure, households' other characteristics influence how households perceive their economic situations. This indicates that factors other than income per capita alone are relevant for understanding households' welfare and their perception of normal life, and, hence, should be among the targets of social policy and factored into the development strategies of Estonia's social protection system. This paper establishes a premise that precise information about households' evaluations of their economic situations and about the main socio-demographic characteristics of households is critical in solidifying a basis around which to develop effective social policy in Estonia.

Estonian people evidently do not receive sufficient social support in order to manage with and adjust accordingly to the tremendous changes imposed by a transitioning society. Lack of support renders the population vulnerable to rapid increases in income inequality and amplification of social exclusion. Thus, in order to counter the causes of deprivation of Estonian society and to meet the requirements for sustainable development, an improvement of social conditions, focusing on bolstering the means to enable both contemporary and future 
generations to attain a goal of well-being, is essential. The prospects for healthy economic growth are intensified under conditions of social cohesion.

\section{Suggestions for Future Research}

As indicated in the study, factors other than income per capita alone are recognized as germane to contextualizing both household welfare and the perceptions which households espouse in defining life as normal. Accordingly, a comprehensive consideration of all relevant factors should be considered when formulating social policy to remedy a given problem. This task is left open to a more all-inclusive study. Furthermore, this study draws a conclusion that, although present-day Estonian society remains characterized by relative deprivation, the citizens' adjustments to abrupt changes inherent in Estonia's transition and integration processes is still underway; what is revealed in the aftermath of convergence and integration is yet to be assessed and thus also remains open for future study.

Lessons derived from the Estonia experience are evidently not unique; parallel insights may be efficaciously transferable to other countries engaged, as is Estonia, in the challenges intrinsic to adherence to requirements of EU eastward enlargement. Researchers who specialize in the study of other countries in transition could contribute further to this vein of literature.

\section{References}

1. Anand, Sudhir; Ravi Kanbur. (1993), "Inequality and Development: A Critique", Journal of Development Economics, Vol. 41, Is. 1, pp. 19-43.

2. Berger-Schmitt, Regina; Heinz-Herberg Noll (2000) Conceptual Framework and Structure of a European System of Social Indicators, EU reporting Working Paper No9, Centre for Survey Research and Methodology, Social Indicators Department, Mannheim.

3. Berghman, Jos (1998) Social Protection and Social Quality in Europe. W. beck, van der Meaesen and A. Walker (eds.) The Social Quality of Europe, Bristol: The Policy Press.

4. Black, John. (1997), Oxford Dictionary of Economics. Oxford, New York: Oxford University Press.

5. $\quad$ European Commission (1998), Social Protection in Europe 1997, Luxembourg.

6. Gaudier, Maryse (1993) Poverty, Inequality, Exclusion: New Approaches to Theory and Practice, International Institute for Labour Studies, Bibliography Series, No 17, Geneva: International Labour Office.

7. Gore, Charles; Figueiredo Jose B. (1997) Social Exclusion and Anti-Poverty Policy: A Debate. International Institute for Labour Studies, Research, No 110, Geneva.

8. Household Living Niveau 2001. (2002), Statistical Office of Estonia, Tallinn.

9. Kutsar, Dagmar; Avo Trumm (eds.). (1999), Poverty Reduction in Estonia. Background and Guidelines. Tartu: Publishing Company of Tartu University.

10. Kuddo, Arvo, Reelika Leetmaa, Lauri Leppik, Mai Luuk, Andres Võrk. (2002), Sotsiaaltoetuste efektiivsus ja mõju tööjõupakkumisele, Tallinn: Poliitikauuringute Keskus Praxis, p. 128.

11. Paas, Tiiu; Raul Eamets, Jaan Masso, Marit Rõõm (2003) Labour Market Flexibility and Migration in the Baltic States: Macro Evidences, Working Paper Series of the University of Tartu, Faculty of Economics and Business Administration, Number 16, Tartu.

12. Poverty Reduction in Estonia, Latvia, and Lithuania. (2000), Riga: UNDP.

13. Rodgers, Gerry; Gore, Charles; Figueiredo Jose B. (1995) Social Exclusion: Rhetoric, Reality, Responses. Geneva: International Labour Office.

14. Silver, H. (1994) Social Exclusion and Social Solidarity: three Paradigms. International Institute for Labour Studies (IILS), Discussion Papers Series No 69; Geneva.

15. Social Protection Committee (2001), Report on Social Inclusion Indicators, Brussels.

16. Suhrcke, Marc (2001), Preferences for Inequality: East vs. West. Hamburg International Institute of Economics HWWA Discussion Paper, No 150. 
17. Wilder Lisa; Mare Viies (2001) Demographics, Poverty and Poverty Relief in Estonia. Ülo Ennuste and Lisa Wilder (eds.). Factors of Convergence: A collection for the Analysis of Estonian Socio-Economic and Institutional Evolution, Estonian Institute of Economics, Tallinn, pp. 105-137.

18. World Bank: http://www.worldbank.org/poverty/inequal/index.htm.

19. Word I-Q.com, http://www.wordiq.com/definition/Poverty_level.

20. Zapf, Wolfgang (1984) individuelle Wohlfahrt: Lebensbedingungen und wahrgenommene Lebensqualität. English translation: Individual welfare: Living conditions and noticed quality of life. W. Glatzer and W. Zapf (Eds.), Lebensqualität in der Bundensrepublik, Frankfurt a.M., New York: Campus.

$\underline{\text { Notes }}$ 